\title{
Physiological, Immunological and Evolutionary Perspectives of Labor as an Inflammatory Process
}

\author{
José Javier Reyes-Lagos ${ }^{\mathrm{a}}$, Juan Carlos Echeverría-Arjonillaa ${ }^{\mathrm{a}}$, Miguel Ángel Peña-Castillo ${ }^{\mathrm{a}}$, \\ Augusto J. Montiel-Castro ${ }^{\mathrm{b}, \mathrm{c}}$ and Gustavo Pacheco-López ${ }^{\mathrm{c}, *}$ \\ ${ }^{a}$ Electrical Engineering Department, Universidad Autonoma Metropolitana (UAM) Campus Iztapalapa, \\ Mexico City, Mexico \\ ${ }^{\mathrm{b}}$ Darwin Center for Evolutionary Thinking (CEDAR), Philosophy Department, Social Sciences and Humanities \\ Division, Universidad Autónoma Metropolitana (UAM) Campus Iztapalapa, Mexico City, Mexico \\ ${ }^{\mathrm{c}}$ Health Sciences Department, Universidad Autonoma Metropolitana (UAM) Campus Lerma, Lerma, Mexico
}

\begin{abstract}
The precise mechanisms for the onset of labor at term remain unknown, yet several studies in humans reveal the role of cytokines in the initiation and maintenance of labor, showing many of the hallmarks of inflammation. Recent findings suggest a possible relationship between the activity of the autonomic nervous system (ANS) and the vagal anti-inflammatory response during labor. Furthermore, the role of vaginal microbiota is particularly important during pregnancy because vaginal dismicrobism is one of the most important mechanisms associated with preterm birth. In this review, we present evidence suggesting that a sterile anti-inflammatory response is manifested to attenuate the excessive inflammation introduced by low-risk labor at term, involving either the action of a cholinergic pathway, uterine-like myokines or the vaginal microbiome.
\end{abstract}

Keywords: Anti-inflammatory response, heart rate variability, vaginal microbiota, pregnancy, labor

\section{INTRODUCTION}

Human pregnancy and labor are physiological scenarios during which the fetal allograft must be tolerated, fed and allowed to grow. The process of labor is mounted to deliver the fetus from the woman's uterus [1]. Parturition is characterized by both cervical ripening and myometrial maturation followed by uterine contractions leading to cervical dilatation and birth [2]. Given that labor seems to be driven by pro-inflammatory cytokines, we suggest that it shows inflammation hallmarks and that the immune privileges that the fetal-placental unit enjoyed during pregnancy are suppressed at the time of labor [3].

\footnotetext{
*Correspondence to: Dr. G. Pacheco-López, UAM-Lerma, Av. de las Garzas 10, Col. El Panteón, Lerma, Edo Mexico, C.P. 52005, México. Tel.: +52 728 2827002; Ext. 2014; E-mail: g.pacheco@ correo.ler.uam.mx.
}

During term and preterm labor different immunological changes are observed, including acute inflammatory features such as an increased influx of leucocytes and an elevated expression of proinflammatory cytokines that have been observed in cervical tissues and fetal membranes [4-6]. Likewise, many studies support the hypothesis that labor involves an inflammatory event [7-13], but more precisely, that human labor should be considered as a sterile inflammatory event mainly because it may be free of microbes triggering labor. According to Rock et al. [14], some sterile pro-inflammatory stimuli, like dead cells, irritant particles (including crystals, minerals and protein aggregates), trauma, immunogenic antigens and autoimmune conditions can cause an inflammatory response. An important finding was that all of such stimuli elicit this inflammation through the same cytokine mediator, interleukin-1 (IL-1) [14]. Given that 
labor implies substantial muscular work involving significant physical efforts, with an important metabolic activity $[15,16]$, we hypothesize that rigorous energy regulation must then be achieved by homoeostatic physiological processes during this final stage of pregnancy where inflammation is also occurring.

Other authors have reported that an inflammatory input activates fast and subconscious antiinflammatory neural responses [17]. In fact, Huston and Tracey [18] defined a neuronal circuit acting as the anti-inflammatory reflex in which the main component is the descending branch of the vagus nerve. Centered on this model, action potentials coming from vagus nerve lead lymphocytes to release acetylcholine that inhibits the production of pro-inflammatory cytokines through $\alpha 7$ nicotinic receptors [18, 19]. This consideration then leads to propose that the observation of the activity of the vagus nerve can provide a suitable tool for measuring an anti-inflammatory reflex in various physiological contexts, thereby supporting a relationship between the activity of the autonomic nervous system (ANS) and an anti-inflammatory response [18]. A conventional noninvasive method to assess the ANS is by analyzing heart rate fluctuations (HRF) data [20]. In general, linear and non-linear methods are applied to obtain measures that are used to estimate parasympathetic and sympathetic activities [20]. Additionally, some studies reinforce the consideration that the cardiovagal activity, quantified by the analysis of HRF data, could provide insights to understand the inmunovagal route [21].

In addition, the role of vaginal microbiota in relation to the process of labor may be particularly important because vaginal dismicrobism is one of the most important mechanisms associated with preterm birth and perinatal complication [22]. Some authors have reported that a probiotic dietary supplementation can be related to a global anti-inflammatory effect on the vaginal immunity, with potential implications in preventing preterm birth [23]. However, most of the vaginal microbiota of pregnant women has been studied during pathological situations such as bacterial vaginosis and aerobic vaginitis [24-28]. As the role of microbiota should not be limited to pathological conditions, we consider necessary to reevaluate the physiological role of vaginal microbiota during pregnancy and its relationship with inflammation.

Current research on the microbiome is exposing several dependencies of the host on microbiota for the maintenance of health, and also the crucial role that endosymbionts may play in the initiation and propagation of disease. Thus, several experimental model systems, including mice, fish, insects, squid and non-human primates, continue providing important insights about the host-microbiota homeostasis [29, 30].

Focused in the physiological process of labor at term, the purpose of this review is to address the following questions linked to labor in healthy women: Is an anti-inflammatory reflex an adaptive response to cope with the excessive inflammation occurring during labor? Could this process be assessed by the analysis of heart rate dynamics, immunological biomarkers and the characterization of vaginal microbiota? To provide some insights into these questions, first we review important issues on the energetic homeostasis during labor. Then, by presenting evidence about the increased vagal modulation during labor at term indicated by HRF data, we focus on the sterile anti-inflammatory reflex. Finally, by means of a comparative approach, we present a few evolutionary aspects of the relationship between vaginal microbiota and pregnancy.

\section{ENERGY HOMEOSTASIS DURING LABOR}

During pregnancy, the fetus requires glucose and amino acids for its growth and development, which sets the pregnant woman to a continuous state of energydemand. Studies of protein and energy metabolism demonstrate the need of regulating the usage of those nutrients $[31,32]$. Fat is deposited in maternal stores throughout pregnancy, providing an energy reserve of $30000 \mathrm{kcal}$ at the end of gestation [31]. Of course this reserve is important to satisfy the fetal requirements, but possibly, also, to confront an important period of energy expenditure caused primarily by an increasing contractile activity in the myometrium during labor. In fact, the maternal heart rate during labor increases up to levels comparable to moderate or heavy exercise [33].

The molecular mechanisms involved in the uterine quiescence during gestation and the induction of labor are not completely known, though it has been demonstrated that the energetic metabolism of the uterine muscle is different between pregnancy and labor [34]. As glucose represents the primary maternal energy reservoir during the first and second stages of labor [35], if labor is prolonged and the source of glucose is limited, gluconeogenesis can be insufficient. During normal labor, the concentration of free fatty acids and ketone bodies increases, leading to the recruitment of substrates other than glucose and a relative reduction of carbohydrates [36, 37]. Thus, labor's efforts 
rapidly decrease the availability of carbohydrates, leading the women's body to metabolize fat for obtaining energy. Consequently, the availability of amino acids in the mother's and fetus' bloodstream is reduced, while the fatty acids and ketones increase [38]. Furthermore, Scheepers et al. suggest that maternal hyperglycemia occurs during labor, leading to increments in maternal and fetal lactate production, resulting in metabolic acidosis [35].

It is well known that, during physical activity, the consumption of energy is linked to the actual duration of this activity [39]. But, given that labor can be extended for several hours (the average time of labor for a primiparous woman is about 16 to 17 hours) [40], it becomes a high energy-demand process similar to that of mid-heavy exercise according to Söhnchen et al. [33]. One may ask how much energy is being used during labor. For instance, if the energy expenditure for a $55 \mathrm{~kg}$ woman during moderate and heavy exercise is between 3.5-7.7 Kcal/min [41], therefore the estimate of energy consumption is $3400-7900 \mathrm{Kcal}$ for a woman during 16 to 17 hours in labor. However, there is few empirical information about energy-expenditure during labor. It has reported as low as 50-100 Kcal per hour of active labor [42] and as high as 300-520 Kcal, Maganha and Peraçoli [43]. Why is this big variation occurring? One likely answer may be related to the differences in energy expenditure between the first and second stages of labor [44]. However, Katz et al. have reported that due to the intermittent character of uterine contractions, normal labor and delivery do not impose high energy demands on the parturient, but that a prolonged labor may result in maternal metabolic disturbances [45]. Thus, these considerations provide opportunity for the realization of future research on this phenomenon.

Other studies indicate that rather than lipids, the pregnant uterine smooth muscle uses glucose as its main nutritive metabolite, and that compared to the striated muscle, the anaerobic pathway of the glucose metabolism is more active in the myometrium [46]. Also, it has been suggested that glucose has a critical role as the principal fuel for ATP formation and both the adenylate kinase and $5^{\prime}$-nucleotidase reactions are involved in any event of glucose shortage [46]. Other studies suggest that glycogen is important because the myometrium content in pregnant rats was found to be increased just prior to parturition [47]. Findings during the latter half of pregnancy in pregnant rats showed gradual increments of insulin binding sites that peaked on the day of parturition [48]. Other findings suggested the effectiveness of insulin in the uterus of pregnant rats, showing that its sensitivity in the myometrium was similar to that observed in skeletal muscle [49]. Thus, myometrium inflammation by means of insulin resistance may be required for maintaining the flow of energy that sustains uterine contractions.

From an immunological point of view, labor can also be considered as an inflammatory event [7-13]. From this perspective, the regulation of energy homeostasis and the immune response is crucial for an organism's survival [50]. For example, in chronic inflammatory diseases, balanced energy-rich fuel supply is largely disturbed due to the vast consumption of an activate immune system [50]. In turn, this process must be occurring during labor as well to fulfill the energy consumption of the mother and fetus. Thus, the maternal immune response and the metabolic regulation should be integrated and the proper function of each must be highly dependent on the other. According to Hotamisligil et al. this interrelation can be viewed as a central homeostatic mechanism [51]. It is well known that an immune response involves a substantial investment of energy [52-54]; therefore, immunity is dependent on a trade-off between other highly demanding energy processes [55]. Labor is a process of energy consumption where the energy-immune trade-off between mother and child is still unclear. Thereby, from this point of view, labor can be regarded as an 'energy demand reaction' caused by the activity of the immune system, the mobilization of fuel stocks (lipolysis/glucogenolysis), and the induction of insulin resistance in liver, adipose tissue and skeletal muscle with the overall purpose of allocating energy-rich fuels to the activated immune cells [50] and, clearly, also the myometrium.

An orthodox trigger inflammation is infection, with the inciting stimulus being certain molecules of the invading microbes. However, several other stimuli, including mechanical trauma, ischemia, toxins, minerals, crystals, chemicals, and antigens, also trigger inflammation in a so called sterile fashion [14]; thereby, we presume that a possible phenomenon of sterile inflammation could be labor itself. Considering that most of the signs and symptoms of inflammation are caused by changes in the local vasculature of an affected tissue [56], in case of spontaneous delivery and preterm labor, there are changes mediated by inflammation in the cervix tissue and the myometrium membranes [3, 4]. As the immune system needs many energy-rich supplies [57], local inflammation must be supported by fuel provision from local or systemic stores. Thus, the participation of an anti-inflammatory response is vital to restrain inflammation [17] and to limit the energy demands. 
This situation then raises the question: Is it possible to identify a sterile inflammatory response during lowrisk labor at term in women?

Any answer to this question should first consider that labor becomes exacerbated by inflammatory process. In fact, pro-inflammatory cytokines such as interleukin: IL-1, IL -6, Tumor Necrosis Factor (TNF- $\alpha$ ), IL-8, IL- 16, Monocyte Chemoattractant Protein 1 (MCP -1), Macrophage Inflammatory Protein (MIP- $1 \alpha$ ), and chemokine CCL5 are all known to be involved as responsible factors for preterm labor [58]. Furthermore, these cytokines are present in high concentrations in the amniotic fluid of patients with infection or inflammation, stimulating uterine contractility by inducing prostaglandins. As it has been demonstrated that the activation of Nuclear factor $\kappa \beta(\mathrm{NF}-\kappa \beta)$ in human myometrium up-regulates inhibitory progesterone isoforms [59], some studies have found that the NF- $\kappa \beta$ is a key modulator of these pathways and acts by regulating the expression of prostaglandins, chemokines and the pro-inflammatory cytokines involved in both term and preterm labor $[1,60]$. The removal of the immunosuppressive and quiescent influences of progesterone by its functional withdrawal may in fact itself be initiated by the inflammation and activation of NF- $\kappa \beta[1,61]$. Therefore, they induce premature labor and birth; yet, apparently, the anti-inflammatory cytokine IL -10 has an important role in regulating the immune response because an increased concentration of it during preterm and labor at term in amniotic fluid has also been identified [58].

\section{A STERILE ANTI-INFLAMMATORY REFLEX DURING LABOR}

As described above, pregnancy itself involves an inflammatory process associated with increased proinflammatory cytokines $[1,4,58,60]$. In this sense, it is also known that progesterone has an immunosuppressive role which promotes the immune privileges of the fetus and regulates the levels of cytokines in the maternal-fetal interface. However, when labor is triggered, these privileges are no longer preserved, causing a sterile inflammation (dilation of cervix, effacement and uterine contractions) and producing pain [3]. Therefore, to oppose this inflammation, the anti-inflammatory cholinergic reflex, among other mechanism explained, could in principle restrain, as in other contexts, the release of pro-inflammatory cytokines [17]. In some conditions, a synergistic coactivation of sympathetic/parasympathetic systems [17] is also manifested through the release of adrenaline/noradrenaline and acetylcholine, respectively. Because pain and fight reflexes are probably manifested during labor, a sympathetic participation may also be involved. Thus, both systems may probably act to down-regulate inflammation (Fig. 1).

Considering the role of myokines [62], it is now recognized that skeletal muscles express and release myokines into the bloodstream in response to muscle contraction by physical activity. Given that muscle fibers express the myokine IL-6, some studies support the relationship between an anti-inflammatory effect of exercise and IL-6 [63, 64] because these myokines stimulate the production of the classical anti-inflammatory cytokines IL-1ra. A direct parallel between the three major myometrial phenotypes (i.e. proliferative, synthetic, and contractile/labor) and the three phases of immunological transformation (i.e. initiation, tolerance and activation) [65] has even been reported, thus pointing to the question over what is the participation of myometrial myokines during labor? Some reports suggest that the stretch of uterine myocytes increases the IL-8 mRNA expression during the onset of labor [66]. Moreover, that the cytokines IL-1 $\beta$, IL- 6 and IL-8 levels are higher in maternal serum during the onset labor than those of non-labor women [67]. By making an analogy between exercise and labor, we hypothetisize that the strong uterine activity induces a sterile anti-inflammatory reflex by means of myokines production.

One of the major triggers of inflammation is infection, being certain molecules of the invading microorganisms the inciting stimuli [68-70]. In this context, because labor must be free of microbes that trigger it, and in comparison with some preterm labors triggered by bacterial infection [22], low-risk labor could be considered as a sterile inflammatory event. However, while the final inflammatory manifestation of labor should be similar between infectious and sterile triggers, the specific control of the response may be different. Thereby, each inflammatory input may activate a distinct anti-inflammatory response; in case of low-risk labor at term a sterile anti-inflammatory response. Results showed that the IL-1 pathway plays a key role in the neutrophilic inflammation to diverse sterile stimuli, including a variety of irritant particles and dead cells [14]. Interestingly, this same cytokine has been implicated in the mechanism of human parturition, because some results showed that pregnant women without labor had undetectable IL-1 $\alpha$ concentration in comparison to a labor group [71]. 


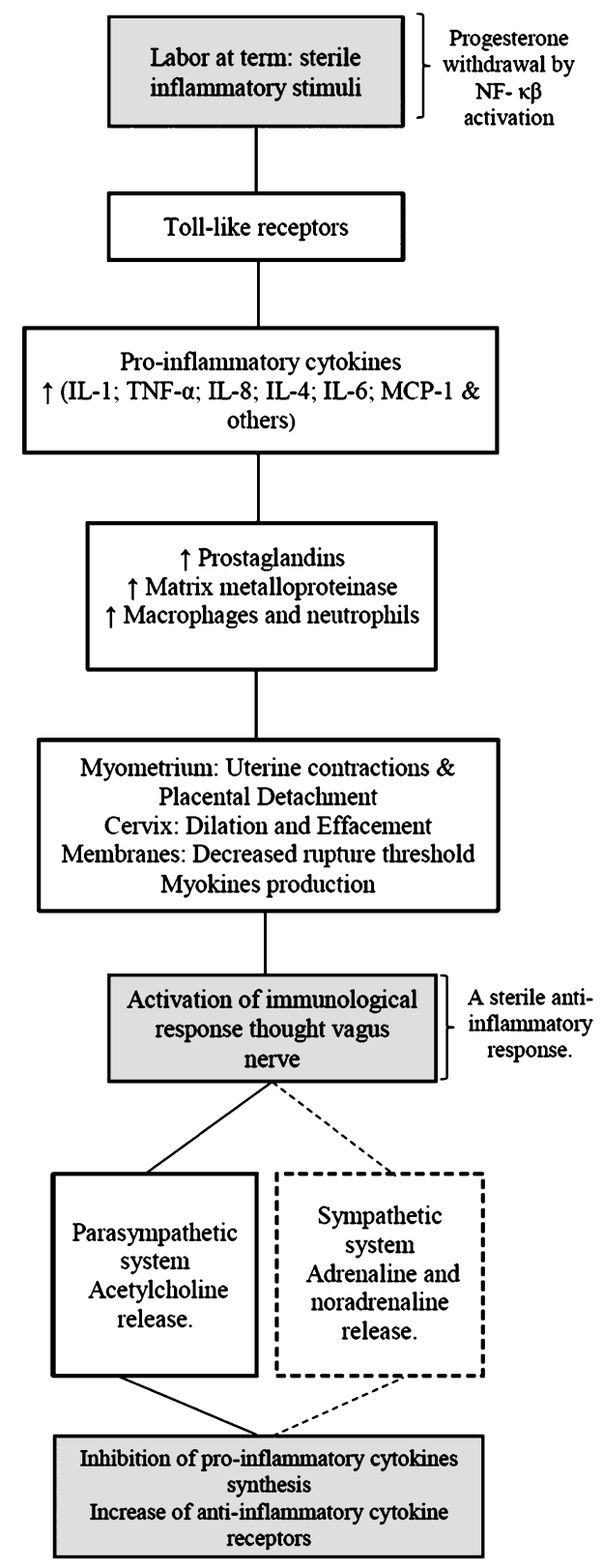

Fig. 1. Diagram of the inflammatory process as a mechanism present during labor and its possible association with a regional anti-inflammatory sterile response. According to Tracey KJ, 2002, this response sometimes presents a synergistic action by the sympathetic/parasympathetic systems to contend with inflammation. Uterine-like myokines and the vaginal microbiome may also be involved (see text). (Image adapted from Peltier MR, Immunology of term and preterm labor, 2003).

\section{INCREASED VAGAL MODULATION DURING LABOR AT TERM}

A noninvasive method to assess the autonomic nervous system (ANS) is the analysis of HRF data. HRF analysis aims to separate and quantify the autonomous cardiac response in sympathetic (adrenergic) and parasympathetic (cholinergic-vagal) influences. The sympathetic and parasympathetic branches of ANS and their influences on heart rate (HR) and HRF are well understood. Sympathetic activity tends to increase HR and decrease HRF, whereas parasympathetic tends to decrease HR and increase HRF [20].

The time intervals between consecutive heart beats are measured in the electrocardiogram (ECG) from the beginning of a QRS complex to the beginning of the next QRS complex. They are conventionally named RR intervals (Fig. 2a). Thus, the HRF is defined as the variation of consecutive RR intervals. Among different mechanisms, this variation depends on the autonomic control of the heart.

A group of researchers began a series of discussions about the role of HRF analysis as an index of autonomic control, concluding that different analysis techniques of HRF provided indices associated with the autonomic control of the heart [72]. Recent studies have specifically linked the cholinergic antiinflammatory activity with changes in some of these HRF indices; thereby, considered as important parameters useful for recording the activity of such pathway [18]. In particular, given that the root mean square of the successive differences (RMSSD) is commonly used as an index of a vagal nerve mediated cardiac control, which is closely linked to respiration via the respiratory sinus arrhythmia (RSA) [73], this is one of the HRF time-domain tools that may be likely linked to the anti-inflammatory cholinergic reflex [74]. Parasympathetic activity can also be quantified by the power-spectral analysis of the HRF, providing the high frequency (HF) index. Which physiological inflammatory processes modify the RMSSD index? For instance, some atopic diseases, such as dermatitis, have been linked to changes in the autonomic modulation towards a higher parasympathetic influence. Patients with dermatitis had higher values of parasympathetic parameters (increased RMSSD) than controls. Therefore, authors have concluded that regional adjustments should be caused by anti-inflammatory cholinergic reflex relieving dermatitis symptoms [75]. Furthermore, other studies reinforce the suggestion that cardiovagal activity, quantified by the analysis of HRF, could provide insights to understand the immunovagal route [21]. Importantly, some clinical studies have also evaluated the relationship between inflammation and HRF parameters in different contexts [76-84].

In a recent study, we explored vagal modulation during labor at term assuming that an anti-inflammatory 
a)
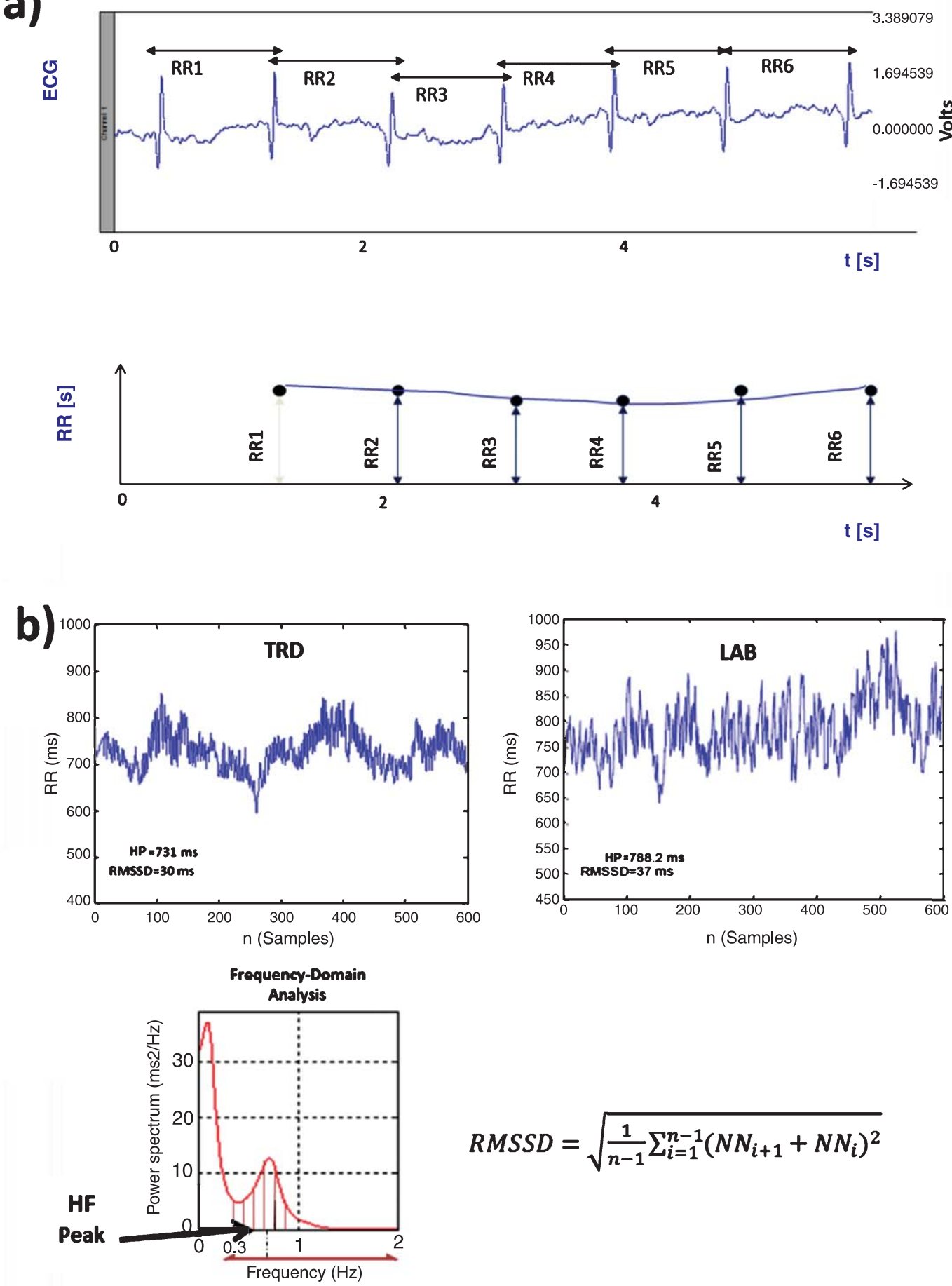

Fig. 2. a) An RR interval is the elapsed time between two successive QRS complexes of the ECG. RR intervals show the variation between consecutive heartbeats. Heart rate fluctuations (HRF) measurements analyze how these RR intervals change over time. b) Typical data of heart beat fluctuations during the last trimester of gestation prior to labor TRD (Left) and during labor at term LAB (Right) segments. Values of the parameters HP and RMSSD calculated for those series are also depicted. Bottom of the figure illustrates how these parameters are obtained. 
cholinergic response was manifested during low-risk labor. Thus, once obtained informed consent, we collected at Maternal and Child Research Center, Mexico City, Mexico (CIMIGen), 10 minutes segments of electrocardiogram (ECG) from 30 women in low-risk labor at the semi-Fowler position (mean age of $26 \pm 5$ years) without any complication and with normal pregnancy outcome: mean APGAR (5 minutes) $8.9 \pm 0.7$ point, gestational age of $40 \pm 1$ weeks and birth weight of $3175 \pm 297 \mathrm{~g}$.

Women received intravenous oxytocin during early labor to improve contractility. The ECG were recorded during periods with low uterine activity or not presenting contractions at all (LAB group), with the purpose that hemodynamic changes due to uterine contractions did not affect the HRF measurements. A second group included HRF data segments collected during the last trimester of gestation prior to labor from a different group of 30 pregnant women (TRD group) with gestational age of $35 \pm 2$ weeks.

A ECG portable device, Monica AN24, was used for data acquisition. Sampling frequency was $900 \mathrm{~Hz}$. Required segments were delineated visually by using the device's software, displaying values of maternal and fetal heart rate among ECG-derived uterine activity.

Raw maternal ECGs were then processed using previous validated algorithms to generate $R R$ intervals or HRF series corresponding to LAB and TRD segments [85]. All series consisted of 600 samples (spanning 5 to 10 minutes duration).

Segments of both groups were analyzed to estimate the average heart period (HP), RMSSD, and HF peak index to estimate the respiration rate [86]. Previous research [87] has shown that the central frequency location of the HF peak of HRF (Fig. 2b) can be an appropriate index of respiration rate. Therefore, the HF component of HRF is a useful proxy for respiration rate when respiration is not directly measured.

RMSSD was estimated as:

$$
R M S S D=\sqrt{\frac{1}{n-1} \sum_{i=1}^{n-1}\left(N N_{i+1}+N N_{i}\right)^{2}}
$$

where $\mathrm{NN}_{\mathrm{i}}$ is the duration of the $\mathrm{i}$-th $\mathrm{NN}$ interval in the analyzed $\mathrm{ECG}$, and $\mathrm{n}$ is the number of all $\mathrm{NN}$ intervals $[20,88]$.

We found RMSSD statistical differences $(p<0.03)$ between LAB and TRD groups $(36 \pm 14 \mathrm{~ms}$ vs. $25 \pm 13 \mathrm{~ms}$, respectively), without affecting neither HP (705 $\pm 100 \mathrm{~ms}$ vs. $705 \pm 90 \mathrm{~ms}$, respectively), nor the
Table 1

Mean values $( \pm \mathrm{SD})$ of parameters of HRF (HP, RMSSD and HF Peak). Gestational age of LAB ( $40 \pm 1$ weeks) vs. gestational age of TRD $(35 \pm 2$ weeks) were statically different $(p<0.00001)$ between LAB and TRD

\begin{tabular}{llcc}
\hline GROUP & HP $(\mathrm{ms})$ & RMSSD $(\mathrm{ms})$ & HF PEAK $(\mathrm{Hz})$ \\
\hline LAB & $705 \pm 100$ & $36 \pm 14^{*}$ & $0.29 \pm 0.06$ \\
TRD & $705 \pm 90$ & $25 \pm 23$ & $0.29 \pm 0.06$ \\
\hline
\end{tabular}

${ }^{*} p<0.03$ between LAB and TRD.

HF peak $(0.29 \pm 0.06 \mathrm{~Hz}$ vs. $0.29 \pm 0.06 \mathrm{~Hz}$, respectively); (Table 1).

These results indicate that the parasympathetic modulation of HRF was increased in the labor group (we found higher levels of RMSSD in LAB vs. TRD groups). This parameter then indicates an increased parasympathetic activity during labor that may reflect a counter-regulatory mechanism to restrain inflammation. Noteworthy, this increment did not affect the HP parameter and thus we can discard differences in the influence of ventilation between TRD and LAB groups as indicated by the HF Peak.

\section{PERINATAL MICROBIOTA}

It is now known that vaginal bacteria commensals, including Lactobacillus crispatus, L. jensenii, and L. rhamnosus, have strong associations with the vaginal epithelial cells. Vaginal bacterial commensals do not trigger cytokine secretion, but as Lactobacilli play and active role to modulate cytokine production [89], bacteria non-commensals can produce an inflammatory process. Also, this consideration is supported by the fact that recent discoveries of variation in the composition of the microbiome of healthy individuals [90-92] show the importance of identifying the processes that could possibly give rise to such variation [93], and there is a rising interest to study microbial community ecology and the healthy microbiota $[94,95]$.

Before considering pregnancy, it is necessary to review how is vaginal microbiota characterized in non-pregnant women. Studies have described the composition of the vaginal microbiota during nonpregnancy: Ravel et al. reported the results of a pyrosequencing analysis of vaginal specimens from a sample of 400 non-pregnant healthy women; they showed that the vaginal microbiota was dominated by Lactobacilli, including $L$ crispatus, $L$ iners, $L$ jensenii and L. gasserii [91]. In accordance with these results, other studies support the observation that species of Lactobacillus dominate vaginal microbiota in most normal and healthy women [96-99]. However, the 
dynamics of the community composition of vaginal microbiota are also affected by the phase of the menstrual cycle, ethnicity, and to a certain extent, sexual activity [100]. Moreover, it must be stressed that the concept of a "normal and healthy" vaginal microbiota is hard to describe without having a full understanding of its role and its effect on women's physiology. According to some studies, one possible way to separate between healthy and unhealthy vaginal microbiota is based on the resulting predisposition to acquire sexually transmitted infections [98, 101].

On the other hand, further evidence indicates that the structure of the vaginal microbiota differs significantly during pregnancy, while other evidence suggests that the microbiota of pregnant women is less diverse and rich (in measured variance) throughout gestation and in proximity to the uterus. According to Aagaard et al. the richness of vaginal microbiota diversity is reduced in pregnancy, with dominance of the Lactobacillus species (L. iners crispatus, jensenii and johnsonii, and the orders Lactobacillales, Clostridiales, Bacteroidales, and Actinomycetales [102]. In this study authors assume that the increased Lactobacillus dominance in the vaginal microbiota during pregnancy may be important for the first inoculum that determines neonate's upper gastrointestinal microbiota upon delivery, or for reducing the risk of ascending infection or preterm birth. In fact, these results may be linked with a remodeling of the gut microbiota over the course of pregnancy. The gut microbiota registered during the first trimester is comparable to that of normal healthy controls, but this similarity shifts substantially (in terms of phylogenetic composition and structure) over the course of pregnancy. By the third trimester an enrichment of Proteobacteria and Actinobacteria is observed in the majority of women [103]. Ottman et al. have reported that the activity and composition of the gut microbiota is affected by genetic background, age, diet, and health status of the host [104].

The possible interactions between gut and vaginal microbiota are caused by the close proximity of the vagina to the anus, exposing the vagina, cervix, and uterus to bacteria and other microorganisms, and somehow giving the intestine flora access to the reproductive tract via the rectum and perineum.

What factors lead to this unbalance or dismicrobism of vaginal microbiota? The incidence of vulvovaginal candidiasis, urinary tract infection, and bacterial vaginosis $(\mathrm{BV})$, among other infections, affect vaginal microbiota [105-108]. For example, during BV the microbiota is dominated by Gardnerella vaginalis
[109] and a number of anaerobic organisms. In contrast, normal flora is dominated by various Lactobacilli producing an acid environment with $\mathrm{pH}$ in the range of 3.5 to 4.5 [110]. Bacterial vaginosis and aerobic vaginitis have been claimed as important mechanisms responsible for preterm birth and perinatal complications [22, 111]. In addition, BV flora predisposes women to infection by the human immunodeficiency virus and sexually transmitted diseases [98]. Additionally, some authors even suggest that, given the hygienic practices of contemporary societies, an excessive use of feminine-hygiene products could cause imbalances in the vaginal microbiota which may promote infection [112].

It is also interesting to understand the mechanisms of defense used in the control of infections; vaginal defenses include: (i) mechanical barriers such as the mucus layer, hemocidin and fibronectin, (ii) host protective enzymes (e. g. lysozyme and lactoferrin), and (iii) host immune responses including the complement system and secretory immunoglobulin A $(\operatorname{IgA})$, all of which are influenced by the vaginal microbiota [113-115]. Another way to sustain a healthy vaginal microbiota could be based on the oral and vaginal administration of probiotics. The application of multi-strain probiotics to improve pregnancy outcomes has already been tested in a pilot study, with some success in terms of modulating immune parameters and vaginal microbiota [23]. Such probiotic supplementation can be associated with a global anti-inflammatory effect on vaginal immunity, with potential implications for preventing preterm birth [23]. Particularly, L. rhamnosus GR-1 is able to up-regulate the anti-inflammatory cytokine interleukin 10 (IL-10) and the colony-stimulating factor 3 (CSF3); and, independently to down-regulate the pro-inflammatory cytokine TNF- $\alpha$ in human placental trophoblast cells [116-118]. Even the TNF- $\alpha$ has been associated with infection-mediated preterm birth [119, 120]. These studies have suggested that the administration of probiotics may help restoring and maintaining a healthy vaginal microbiota, and thus, that some probiotic strains seem to have the ability to interfere with the inflammatory pathway leading to premature delivery. Findings such as these lead us to suggest that some kind of immune modulation by the vaginal microbiota may be opposing the exacerbated inflammation process observed during labor.

Now, which is the importance of the vaginal microbiota for the newborn? At the time of birth, the newborn is exposed to maternal microbiota [121-124]. The passage through the genital tract is an essential part 
of this process because the mode of delivery alters the neonatal microbiome [121-126]. In this context, Dominguez-Bello et al. have shown that vaginallydelivered newborns acquired bacterial communities resemble their own mother's vaginal microbiota (dominated by Lactobacillus, Prevotella, or Sneathia spp.); and that caesarian section newborns harbored bacterial communities that were more similar to those found on the skin surface, dominated by Staphylococcus, Corynebacterium, and Propionibacterium spp. [121]. Other results indicate that Lactobacillus found in the maternal vagina influence the development of the neonatal immune system [127]. Maternal antibiotics during labor were associated with a decreased transmission rate of vaginal Lactobacillus flora to the neonate during birth, which may have a preventive role in the development of allergic diseases in the newborn [128]. This evidence could be supported by the findings of Reid et al., because they have found that in some cases of bacterial infections, nonspecific antibiotics are used, killing the non-pathogenic members of the microbiota as well as the pathogens and leading to a substantial delay in the restoration of a healthy microbiota [129].

\section{EVOLUTIONARY PERSPECTIVES}

As in humans, several taxa have developed associations with microbial life, affecting different aspects of their health, sociality and reproduction [e.g., insects 130, 131; aquatic organisms 132; amphibians 133; reptiles 134-136; birds 137, 138; carnivores 139, 140, primates 141, 142]. Accordingly, the vaginal microbiota may also be regarded as a symbiotic relationship. Symbioses are believed to be ancient, as they involve a long history of interdependence and natural selection involving the coevolution of microbial and host traits that reinforce the relationship [143].

Different species use a variety of behaviors which, acting also as social bonding mechanisms, may allow for the direct and indirect transmission of microbiota [144], including licking [145] and grooming [146]. For instance, crucial to regulation of mammalian development are maternal biochemicals provided to offspring through lactation [147]: an ancient adaptation arising several million years ago, with the function of protecting the product from both desiccation and colonization by microbial pathogens [148]. A study by Bailey and Coe [149] signals the importance of the mother-infant relationship. These authors found that in infant rhesus monkeys, the integrity of their micro- biota suffered important modifications after separation from their mothers, suggesting that this social disruption lead to an internal environment that was more prone to infection by pathogens. Indeed, it is during suckling when infants receive specific microbe strains from their mothers [150]. A variety of milk components nourish a newborn by providing the compounds that promote growth, modulate the immune system, promote cognitive development and help establishing a normal gastrointestinal microbiota [151]. For example, human milk contains large amounts of oligosaccharides that are not directly assimilated by infants. Instead, these oligosaccharides feed the bacteria $B$. longum infantis, a primary link in the process of infant's nutrition that helps modulating the immune responses in the intestines and with an important role in the bioconversion of digested nutrients [152]. Some authors have suggested that, compared to that found in other primates and probably due to their beneficial microbiological properties, the significantly greater oligosaccharide concentration found in human milk could have been selected based on the particular disease ecology of humans [153].

Recent developments in metagenomic methods allow the identification of the microbial communities composition by means of DNA sequencing, without the need for specific cultures, providing important insights into within and inter-individual variation [154]. Evidence suggests that, in contrast to bacterial communities found in non-human primates and as described before, the healthy human vaginal microbiota is characteristically dominated by the presence of Lactobacillus [30]. Such findings allow asking about the selective pressures leading to the establishment of this relationship across the evolutionary history of the organisms involved. Stumpf et al. [30] have recently suggested three hypotheses explaining the comparative uniqueness of the human vaginal microbiome. Their first argument is that, given that the abundant Lactobacillus are related to estrogen levels in women of reproductive age, their presence could be related to differences in the reproductive cycles between humans and non-human primates. As the vaginal microbiota of most other nonhuman primates of reproductive age resembles that of non-reproductive human females, its presence could offer protective advantages from pathogens during the crucial periovulatory periods [30]. In this sense, comparative evidence from apes suggests that menopause is not common among chimpanzees [155], gorillas [156] or orangutans [157], and therefore, that the abundant presence of Lactobacillus and menopause could be both derived features of the human life-cycle [155, 


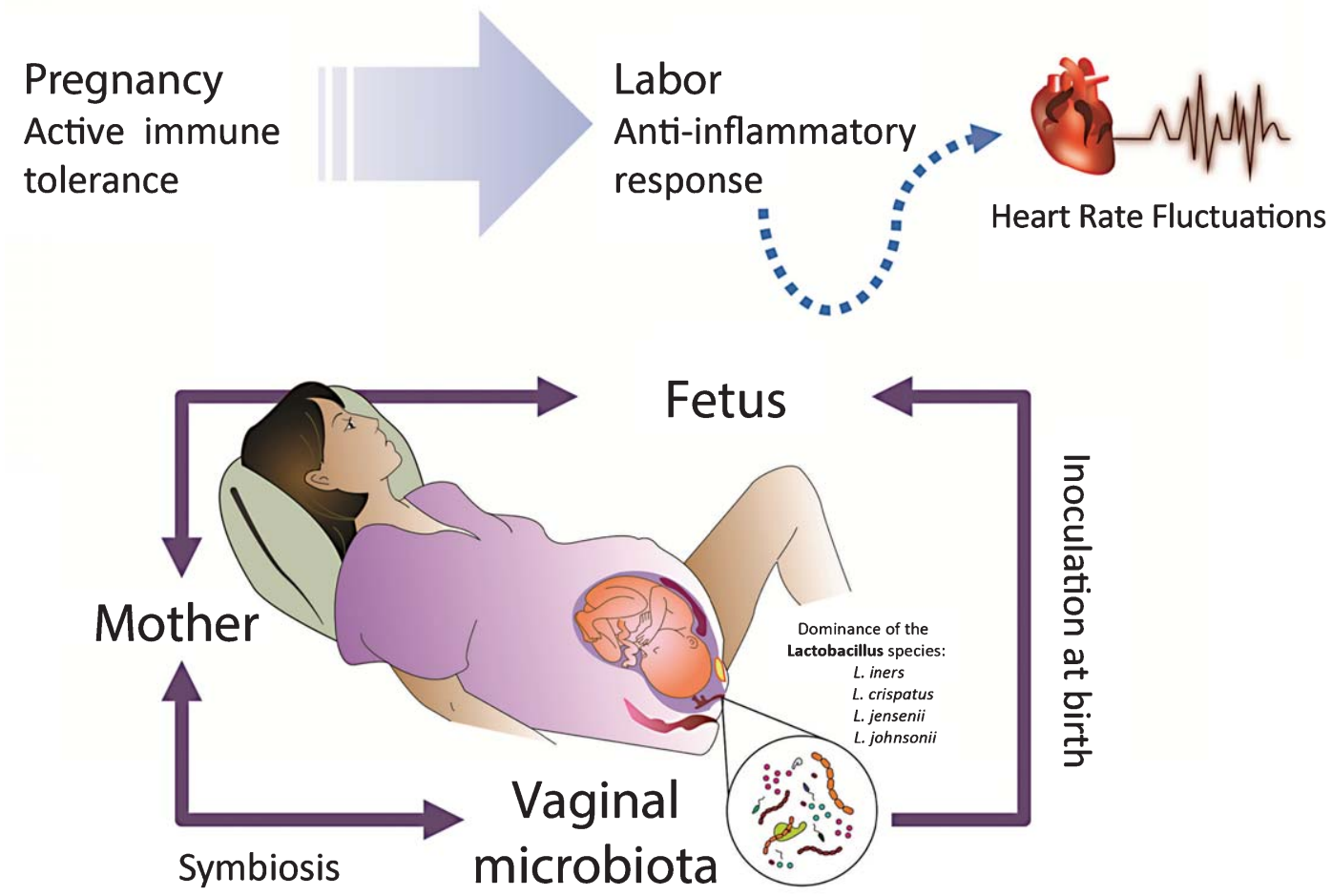

Fig. 3. Suggested interaction among mother, fetus and vaginal microbiota during labor. A sterile anti-inflammatory response is manifested during low-risk labor at term, by either the action of a cholinergic pathway, uterine-like myokines or vaginal microbiome (Image adapted from [159]).

158]. The second hypothesis of Stumpf et al. is that the uniqueness of the human vaginal microbiome may be related to human's unique sexuality, i.e., the continuous female sexual receptivity increases females exposure to greater risks of infection and thus a symbiosis that could, somehow, minimize such risks would be highly advantageous and selected. Perhaps current developments involving the primate vaginal microbiome should focus research efforts on the wide variety of primate's reproductive systems and expand our knowledge on this aspect of the distinctiveness of the human primate [30]. Last but not least, by means of an "obstetric protection hypothesis", Stumpf et al. suggest that the size of the product in relation to the size of the pelvic outlet could increase the risks of infection to the mother and the fetus, and therefore that a symbiosis reducing such risks would be highly advantageous [30].

\section{CONCLUSION}

On the basis of this review, we consider lowrisk labor at term as a sterile inflammatory event where three important entities come into interplay (Fig. 3). The first is the mother, whose HRF analysis provides a non-invasive tool to disentangle the role of the anti-inflammatory vagal reflex during labor. The second entity is the vaginal microbiota, where its immunomodulation properties may be based on the modification of bacterial colonies; in particular, the family of Lactobacilli seems to play a key role in this process. The final entity is the fetus, playing an important role on the labor process; the fetal heart rate fluctuations may also represent another important marker to understand more about the antiinflammatory process during the process of labor. While this is a promising path for future research, in this review we have focused our efforts in underlying the primary role of the mother.

\section{ACKNOWLEDGMENTS}

The support of volunteer mothers and staff of CIMIGen is gratefully acknowledged. J. Javier ReyesLagos thanks the Mexican Council for Science and 
Technology (CONACyT) for providing fellowship (CVU/Fellowship number: 381983/253449).

\section{CONFLICT OF INTEREST}

Authors report no conflict of interest.

\section{REFERENCES}

[1] Golightly E, Jabbour HN, Norman JE. Endocrine immune interactions in human parturition. Mol Cell Endocrinol. 2011; 335(1): 52-59.

[2] Norwitz ER, Robinson JN, Challis JR. The control of labor. N Engl J Med. 1999; 341(9): 660-666.

[3] Peltier MR. Immunology of term and preterm labor. Rep Biol End. 2003; 1(122): 1-11.

[4] Challis JR, Lockwood CJ, Myatt L, Norman JE, Strauss JF, Petraglia F. Inflammation and pregnancy. Reprod Sci. 2009; 16(2): 206-215.

[5] Houben ML, Nikkels PG, Van GM, Visser GH, Rovers MM, Kessel H, de Waal WJ, Schuijff L, Evers A, Kimpen JL, Bont L. The association between intrauterine inflammation and spontaneous vaginal delivery at term: A cross-sectional study. PLoS One. 2009; 4(8): e6572.

[6] Dubicke A, Fransson E, Centini G, Andersson E, Byström B, Malmström A,Petraglia F, Sverremark-Ekström E, EkmanOrdeberg G: Pro-inflammatory and anti-inflammatory cytokines in human preterm and term cervical ripening. $\mathrm{J}$ Reprod Immunol. 2010; 84(2): 176-185.

[7] Osman I, Young A, Ledingham MA., Thomson AJ, Jordan F, Greer IA, Norman JE. Leukocyte density and pro-inflammatory cytokine expression in human fetal membranes, decidua, cervix and myometrium before and during labour at term. Mol Hum Reprod. 2003; 9(1): 41-45.

[8] Thomson AJ, Telfer JF, Young A, Campbell S, Stewart CJ, Cameron IT, Greer IA, Norman JE. Leukocytes infiltrate the myometrium during human parturition: Further evidence that labour is an inflammatory process. Hum Reprod. 1999; 14(1): 229-236.

[9] Ledingham MA, Thomson AJ, Jordan F, Young A, Crawford M, Norman JE. Cell adhesion molecule expression in the cervix and myometrium during pregnancy and parturition. Obstet Gynecol. 2001; 97(2): 235-242

[10] Winkler M, Fischer DC, Ruck P, Horny HP, Kemp B, Rath W. Cytokine concentrations and expression of adhesion molecules in the lower uterine segment during parturition at term: Relation to cervical dilatation and duration of labor. Z Geburtshilfe Neonatol. 1998; 202(4): 172-175.

[11] Sennstrom MB, Ekman G, Westergren-Thorsson G, Malmstrom A, Bystrom B, Endresen U, Mlambo N, Norman M, Stabi B, Brauner A. Human cervical ripening, an inflammatory process mediated by cytokines. Mol Hum Reprod. 2000; 6(4), 375-381.

[12] Yuan M, Jordan F, McInnes IB, Harnett MM, Norman JE. Leukocytes are primed in peripheral blood for activation during term and preterm labour. Mol Hum Reprod. 2009; 15(11): 713-724.

[13] Young A, Thomson AJ, Ledingham M, Jordan FG, IA, Norman JE. Immunolocalization of proinflammatory cytokines in myometrium,cervix, and fetal membranes during human parturition at term. Biol Reprod. 2002; 66(2): 445-449.
[14] Rock KL, Latz E, Ontiveros F, Kono H. The sterile inflammatory response. Annu Rev Immunol. 2010; 28: 321-342.

[15] Sloane E, Biology of Women, 4th ed, New York: Wiley, 2001.

[16] DeCherney AH, Pernoll ML. Current obstetric \& gynecologic diagnosis \& treatment. 10th ed. Norwalk, Conn: Appleton \& Lange, 1994.

[17] Tracey KJ. The Inflammatory Reflex. Nature. 2002; 420(6917): 853-859.

[18] Huston JM, Tracey KJ. The pulse of inflammation: Heart rate variability, the cholinergic anti-inflammatory pathway and implications for therapy. J Intern Med. 2011; 269(1): 45-53.

[19] Rosas-Ballina M, Olofsson PS, Ochani M, Valdés-Ferrer SI, Levine YA, Reardon C, Tusche MW, Pavlov VA, Andersson U, Chavan S, Mak TW, Tracey KJ. Acetylcholinesynthesizing $\mathrm{T}$ cells relay neural signals in a vagus nerve circuit. Science. 2011; 334(6052): 98-101.

[20] Task Force of the European Society of Cardiology and the North American Society of Pacing and Electrophysiology. Heart rate variability: Standards of measurement, physiological interpretation and clinical use. Euro H J. 1996; 17(3): 354-381.

[21] Tonhajzerova I, Mokra D, Visnovcova Z. Vagal function indexed by respiratory sinus arrhythmia and cholinergic anti-inflammatory pathway. Respir Physiol Neurobiol. 2013; 187(1): 78-81.

[22] Donati L, Di Vico A, Nucci M, Quagliozzi L, Spagnuolo T, Labianca A, Bracaglia M, Ianniello F, Caruso A, Paradisi G. Vaginal microbial flora and outcome of pregnancy. Arch Gynecol Obstet. 2010; 281: 589-600.

[23] Vitali B, Cruciani F, Baldassarre ME, Capursi T, Spisni E, Valerii MC, Candela M, Turroni S, Brigidi P. Dietary supplementation with probiotics during late pregnancy: Outcome on vaginal microbiota and cytokine secretion. BMC Microbiol. 2012; 12: 236.

[24] Goldenberg RL, Culhane JF, Iams JD, Romero R. Epidemiology and causes of preterm birth. Lancet. 2008; 371 : 75-84.

[25] Hillier SL, Nugent RP, Eschenbach DA, Krohn MA, Gibbs RS, Martin DH, Cotch MF, Edelman R, Pastorek JG, Rao AV, McNellis D, Regan JA, Carey JC, Klebanoff MA. Association between bacterial vaginosis and preterm delivery of a low-birth-weight infant. The vaginal infections and prematurity study group. N Engl J Med. 1995; 333: 1737-1742.

[26] McGregor JA, French JI. Bacterial vaginosis in pregnancy. Obstet Gynecol Surv. 2000; 55(5 Suppl 1): 1-19.

[27] Beigi RH, Yudin MH, Cosentino L, Meyn LA, Hillier SL. Cytokines, pregnancy, and bacterial vaginosis: Comparison of levels of cervical cytokines in pregnant and nonpregnant women with bacterial vaginosis. J Infect Dis. 2007; 196: 1355-1360.

[28] Mattsby-Baltzer I, Platz-Christensen JJ, Hosseini N, Rosén P. IL-1beta, IL-6, TNFalpha, fetal fibronectin, and endotoxin in the lower genital tract of pregnant women with bacterial vaginosis. Acta Obstet Gynecol Scand. 1998; 77: 701-706.

[29] Kostic AD, Howitt MR, Garrett WS. Exploring hostmicrobiota interactions in animal models and humans. Genes Dev. 2013; 1;27(7): 701-718.

[30] Stumpf RM, Wilson BA, Rivera A, Yildirim S, Yeoman CJ, et al. The primate vaginal microbiome: Comparative context and implications for human health and disease. Am J Phys Anthr. 2013; 152(S57): 119-134.

[31] King JC. Physiology of pregnancy and nutrient metabolism. Am J Clin Nutr. 2000; 71(5 Suppl): 1218S-1225S. 
[32] Scheepers HC, de Jong PA, Essed GG, Kanhai HH. Carbohydrate solution intake during labour just before the start of the second stage: A double-blind study on metabolic effects and clinical outcome. BJOG. 2004; 111(12): 1382-1387.

[33] Söhnchen N, Melzer K, Tejada BM, Jastrow-Meyer N, Othenin-Girard V, Irion O, Boulvain M, Kayser B. Maternal heart rate changes during labour. Eur J Obstet Gynecol Reprod Biol. 2011; 158(2): 173-178.

[34] Laudański T. Energy metabolism of the myometrium in pregnancy and labor. Zentralbl Gynakol. 1985; 107(9): 568573.

[35] Scheepers HC, de Jong PA, Essed GG, Kanhai HH. Fetal and maternal energy metabolism during labor in relation to the available caloric substrate. J Perinat Med. 2001; 29(6): 457-464.

[36] Kashyap ML. Carbohydrate and lipid metabolism during human labor: Free fatty acids, glucose, insulin and lactic acid metabolism during normal and oxytocin-induced labor for postmaturity. Metabolism. 1976; 25: 865-871.

[37] Felig P, Lynch V. Starvation in human pregnancy; Hypoglycemia, hypoinsulinemia and hyperketonemia. Science. 1970; 170: 990.

[38] Keppler AB. The use of intravenous fluids during labor. Birth. 1988; 15: 75-79.

[39] Wood C, Ng KH, Honslow D. Time - an important variable in normal delivery. J Obstet Br Commonw. 1973; 80: 295300 .

[40] Limmer D, et al. Emergency Care. 9th ed. Englewood Cliffs, New Jersey: Prentice Hall, 2000.

[41] McArdle WD, Katch FI, Katch VL. Exercise Physiology: Energy Nutrition and Human Performance. 6th ed. Baltimore, MD: Lippincott Williams \& Wilkins; 2007.

[42] Marchese T, Coughlin JH, Adams CJ. Nurse midwifery: Health care for women and newborns. J Nurse Midwifery. 1983; 18: 115-75.

[43] Maganha e Melo CR, Peraçoli JC. Measuring the energy spent by parturient women in fasting and in ingesting caloric replacement (Honey). Rev Lat Am Enfermagem. 2007; 15(4): 612-617.

[44] Banerjee B, Khew KS, Saha N, Ratnam SS. Energy cost and blood sugar level during different stages of labour and duration of labour in Asiatic women. J Obstet Gynaecol Br Commonw. 1971; 78(10): 927-929.

[45] Katz M, Kroll D, Shapiro Y, Cristal N, Meizner I. Energy expenditure in normal labor. Isr J Med Sci. 1990; 26(5): 254-257.

[46] Steingrímsdóttir T, Ronquist G, Ulmsten U, Waldenström A. Different energy metabolite pattern between uterine smooth muscle and striated rectus muscle in term pregnant women. Eur J Obstet Gynecol Reprod Biol. 1995; 62(2): 241-245.

[47] Chew CS, Rinard GA. Glycogen levels in the rat myometrium at the end of pregnancy and immediately postpartum. Biol Reprod. 1979; 20(5): 1111-1114.

[48] Sakamoto H, Leranth C, MacLusky NJ, Saito Y, Naftolin F. Insulin specific binding sites in the myometrium of pregnant rats. Endocrinology. 1987; 120(5): 1951-1955.

[49] Figueroa H, Marusic E, Gonzalez M, Barcos F, Yungue P. Efecto in vitro de la insulina sobre la capacidad contráctil uterina inducida por oxitocina. Rev Chil Obstet Genecol. 2002; 67(3): 184-189.

[50] Straub RH, Cutolo M, Buttgereit F, Pongratz G. Energy regulation and neuroendocrine-immune control in chronic inflammatory diseases. J Intern Med. 2010; 267(6): 543-560.

[51] Hotamisligil GS. Inflammation and metabolic disorders. Nature. 2006; 444(7121): 860-867.
[52] Sadd BM, Schmid-Hempel P. Principles of ecological immunology. Evol Appl. 2008; 2: 113-121.

[53] Demas GE. The energetics of immunity: A neuroendocrine link between energy balance and immune function. Horm Behav. 2004; 45: 173-180.

[54] Lochmiller RL, Deerenberg C. Trade-offs in evolutionary immunology. Oikos. 2000; 88: 87-98.

[55] Pacheco-López G, Bermúdez-Rattoni F. Brain-immune interactions and the neural basis of disease-avoidant ingestive behaviour. Philos Trans R Soc Lond B BiolSci. 201; 366(1583): 3389-3405.

[56] Majno G. Cells, Tissues and Diseases: Principles of General Pathology. 2nd ed. Cambridge, MA: Oxford Univ. Press, 2004.

[57] Buttgereit F, Burmester GR, Brand MD. Bioenergetics of immune functions: Fundamental and therapeutic aspects. Immunol. Today. 2000; 21: 192-199.

[58] Gotsch F, Romero R, Kusanovic JP, Erez O, Espinoza J, Kim CJ, Vaisbuch E, Than NG, et al. The anti-inflammatory limb of the immune response in preterm labor, intra-amniotic infection/inflammation, and spontaneous parturition at term: A role for interleukin-10. J Matern Fetal Neonatal Med. 2008; 21(8): 529-547.

[59] Condon JC, Hardy DB, Kovaric K, Mendelson CR. Upregulation of the progesterone receptor (PR)-C isoform in laboring myometrium by activation of nuclear factorkappaB may contribute to the onset of labor through inhibition of PR function. Mol Endocrinol. 2006; 20(4): 764-775.

[60] MacIntyre DA, Sykes L, Teoh TG, Bennett PR. Prevention of preterm labour via the modulation of inflammatory pathways. J Matern Fetal Neonatal Med. 2012; 25(Suppl 1): $17-20$

[61] Szekeres-Bartho J, Wilczynski JR, Basta P, Kalinka J. Role of progesterone and progestin therapy in threatened abortion and preterm labour. Front Biosci. 2008; 13: 1981-1990.

[62] Pedersen BK. Muscles and their myokines. J Exp Biol. 2011; 214(Pt 2): 337-46

[63] Starkie R, Ostrowski SR, Jauffred S, Febbraio M, Pedersen BK. Exercise and IL-6 infusion inhibit endotoxin-induced TNF-alpha production in humans. FASEB J. 2003; 17: 884886.

[64] Steensberg A, Fischer CP, Keller C, Moller K, Pedersen BK. IL- 6 enhances plasma IL-1ra, IL-10, and cortisol in humans. Am J Physiol Endocrinol Metab. 2002; 285: E433-E437.

[65] Shynlova O, Lee YH, Srikhajon K, Lye SJ. Physiologic uterine inflammation and labor onset: Integration of endocrine and mechanical signals. Reprod Sci. 2013; 20(2): 154-167.

[66] Loudon JA, Sooranna SR, Bennett PR, Johnson MR. Mechanical stretch of human uterine smooth muscle cells increases IL-8 mRNA expression and peptide synthesis. Mol Hum Reprod. 2004; 10(12): 895-899.

[67] Hebisch G, Neumaier-Wagner PM, Huch R, von Mandach U. Maternal serum interleukin- 1 beta, -6 and -8 levels and potential determinants in pregnancy and peripartum. J Perinat Med. 2004; 32(6): 475-480.

[68] Medzhitov R. Origin and physiological roles of inflammation. Nature. 2008; 454: 428-435.

[69] Akira S, Uematsu S, Takeuchi O. Pathogen recognition and innate immunity. Cell. 2006; 124: 783-801.

[70] Inohara C, McDonald C, Nunez G. NOD-LRR proteins: Role in host-microbial interactions and inflammatory disease. Annu Rev Biochem. 2005; 74: 355-83.

[71] Romero R, Mazor M, Brandt F, Sepulveda W, Avila C, Cotton DB, Dinarello CA. Interleukin-1 alpha and interleukin-1 
beta in preterm and term human parturition. Am J Reprod Immunol. 1992; 27(3-4): 117-123.

[72] Parati G, Mancia G, Di Rienzo M, Castiglioni P, Taylor JA, Studinger P. Point-Counterpoint: Cardiovascular variability is/is not an index of autonomic control of circulation. J Appl Physiol. 2006; 101: 676-682.

[73] Berntson GG, Lozano DL, Chen YJ. Filter properties of root mean square successive difference (RMSSD) for heart rate. Psychophysiology. 2005; 42(2): 246-252.

[74] Thayer JF, Fischer JE. Heart rate variability, overnight urinary norepinephrine and C-reactive protein: Evidence for the cholinergic anti-inflammatory pathway in healthy human adults. J Intern Med. 2009; 265(4): 439-447.

[75] Boettger MK, Bär KJ, Dohrmann A, Müller H, Mertins L, Brockmeyer NH, Agelink MW. Increased vagal modulation in atopic dermatitis. J Dermatol Sci. 2009; 53(1): 55-59.

[76] Godin PJ, Fleisher LA, Eidsath A, Vandivier RW, Preas HL, Banks SM, Buchman TG, Suffredini AF. Experimental human endotoxemia increases cardiac regularity: Results from a prospective, randomized, crossover trial. Crit Care Med. 1996; 24(7): 1117-1124.

[77] Lehrer P, Karavidas MK, Lu SE, Coyle SM, Oikawa LO, Macor M, Calvano SE, Lowry SF. Voluntarily produced increases in heart rate variability modulate autonomic effects of endotoxin induced systemic inflammation: An exploratory study. Appl Psychophysiol Biofeedback. 2010; 35(4): 303-315.

[78] Chuang HC, Hsueh TW, Chang CC, Hwang JS, Chuang KJ Yan YH, Cheng TJ. Nickel-regulated heart rate variability: The roles of oxidative stress and inflammation. Toxicol Appl Pharmacol. 2013; 266(2): 298-306.

[79] Alvarez SM, Katsamanis Karavidas M, Coyle SM, Lu SE, Macor M, Oikawa LO, Lehrer PM, Calvano SE, Lowry SF. Low-dose steroid alters in vivo endotoxin-induced systemic inflammation but does not influence autonomic dysfunction. J Endotoxin Res. 2007; 13(6): 358-368.

[80] Kox M, Ramakers BP, Pompe JC, van der Hoeven JG, Hoedemaekers CW, Pickkers P. Interplay between the acute inflammatory response and heart rate variability in healthy human volunteers. Shock. 2011; 36(2): 115-120.

[81] Gholami M, Mazaheri P, Mohamadi A, Dehpour T, Safari F, Hajizadeh S, Moore KP, Mani AR. Endotoxemia is associated with partial uncoupling of cardiac pacemaker from cholinergic neural control in rats. Shock. 2012; 37(2): 219227.

[82] Huang J, Wang Y, Jiang D, Zhou J, Huang X. The sympathetic-vagal balance against endotoxemia. J Neural Transm. 2010; 117(6): 729-735.

[83] Jan BU, Coyle SM, Macor MA, Reddell M, Calvano SE, Lowry SF. Relationship of basal heart rate variability to in vivo cytokine responses after endotoxin exposure. Shock. 2010; 33(4): 363-368

[84] Jan BU, Coyle SM, Oikawa LO, Lu SE, Calvano SE, Lehrer PM, Lowry SF. Influence of acute epinephrine infusion on endotoxin-induced parameters of heart rate variability: A randomized controlled trial. Ann Surg. 2009; 249(5): 750756.

[85] Echeverría JC, Ortiz R, Ramírez N, Medina V, González R. A reliable method for abdominal ECG signal processing. In: Proceedings of Computers in Cardiology 1998, sep 13-16; Cleveland, OH, USA, pp. 529-532.

[86] Tarvainen MP, Niskanen JP, Lipponen JA, Ranta-Aho PO, Karjalainen PA. Kubios HRV - heart rate variability analysis software. Comput Methods Programs Biomed. 2014; 113(1): 210-220.
[87] Thayer JF, Peasley C, Muth ER. Estimation of respiratory frequency from autoregressive spectral analysis of heart period. Biomed Sci Instrum 1996; 32: 93-99.

[88] Malik M. Time-Domain Measurement of Heart Rate Variability. Cardiac Electrophysioogy Rev. 1997; 1(3): 329-334.

[89] Rose WA 2nd, McGowin CL, Spagnuolo RA, Eaves-Pyles TD, Popov VL, Pyles RB. Commensal bacteria modulate innate immune responses of vaginal epithelial cell multilayer cultures. PLoS One. 2012; 7(3): e32728.

[90] Palmer C, Bik EM, DiGiulio DB, Relman DA, Brown PO. Development of the human infant intestinal microbiota. PLoS Biol. 2007; 5(7): e177.

[91] Ravel J, Gajer P, Abdo Z, Schneider GM, Koenig SS, McCulle SL, Karlebach S, Gorle R, Russell J, Tacket CO, Brotman RM, Davis CC, Ault K, Peralta L, Forney LJ. Vaginal microbiome of reproductive-age women. Proc Natl Acad Sci U S A. 2011; 108(Suppl 1): 4680-4687.

[92] Wu GD, Chen J, Hoffmann C, Bittinger K, Chen YY, Keilbaugh SA, Bewtra M, Knights D, Walters WA, Knight R, Sinha R, Gilroy E, Gupta K, Baldassano R, Nessel L, Li H, Bushman FD, Lewis JD. Linking long-term dietary patterns with gut microbial enterotypes. Science. 2011; 334(6052): 105-108.

[93] Costello EK, Stagaman K, Dethlefsen L, Bohannan BJ, Relman DA. The application of ecological theory toward an understanding of the human microbiome. Science. 2012; 8; 336(6086): 1255-1262.

[94] Mihaljevic JR. Linking metacommunity theory and symbionts evolutionary ecology. Trends Ecol Evol. 2012; 27(6): 323-329.

[95] Prosser JI, Bohannan BJ, Curtis TP, Ellis RJ, Firestone MK, Freckleton RP,Green JL, Green LE, Killham K, Lennon JJ, Osborn AM, Solan M, van der Gast CJ, Young JP. The role of ecological theory in microbial ecology. Nat Rev Microbiol. 2007; 5(5): 384-392.

[96] Donders GG, Bosmans E, Dekeersmaecker A, Vereecken A, Van Bulck B, Spitz B. Pathogenesis of abnormal vaginal bacterial flora. Am J Obstet Gynecol. 2000; 182(4): 872-878.

[97] Gupta K, Stapleton AE, Hooton TM, Roberts PL, Fennell $\mathrm{CL}$, Stamm WE. Inverse association of H2O2-producing lactobacilli and vaginal Escherichia coli colonization in women with recurrent urinary tract infections. J Infect Dis. 1998; 178(2): 446-450.

[98] Martin HL, Richardson BA, Nyange PM, Lavreys L, Hillier SL, Chohan B, Mandaliya K, Ndinya-Achola JO, Bwayo J, Kreiss J. Vaginal lactobacilli, microbial flora, and risk of human immunodeficiency virus type 1 and sexually transmitted disease acquisition. J Infect Dis. 1999; 180(6): 1863-1868.

[99] Sobel JD. Is There a Protective Role for Vaginal Flora? Curr Infect Dis Rep. 1999; 1(4): 379-383.

[100] Gajer P, Brotman RM, Bai G, Sakamoto J, Schütte UM, Zhong X, Koenig SS, Fu L, Ma ZS, Zhou X, Abdo Z, Forney LJ, Ravel J. Temporal dynamics of the human vaginal microbiota. Sci Transl Med. 2012; 4(132): 132ra52.

[101] Cherpes TL, Meyn LA, Krohn MA, Lurie JG, Hillier SL. Association between acquisition of herpes simplex virus type 2 in women and bacterial vaginosis. ClinInfect Dis. 2003; 37(3): 319-325.

[102] Aagaard K, Riehle K, Ma J, Segata N, Mistretta TA, Coarfa C, Raza S, Rosenbaum S, Van den Veyver I, Milosavljevic A, Gevers D, Huttenhower C, Petrosino J, Versalovic J. A metagenomic approach to characterization of the vaginal microbiome signature in pregnancy. PLoS One. 2012; 7(6): e36466. 
[103] Koren O, Goodrich JK, Cullender TC, Spor A, Laitinen K, Bäckhed HK, GonzalezA, Werner JJ, Angenent LT, Knight R, Bäckhed F, Isolauri E, Salminen S, Ley RE. Host remodeling of the gut microbiome and metabolic changes during pregnancy. Cell. 2012; 150(3): 470-480.

[104] Ottman N, Smidt H, de Vos WM, Belzer C. The function of our microbiota: Who is out there and what do they do? Front Cell Infect Microbiol. 2012; 2: 104.

[105] Dielubanza EJ, Schaeffer AJ. Urinary tract infections in women. Med Clin North Am. 2011; 95: 27-41.

[106] Quan M. Vaginitis: Diagnosis and management. Postgrad Med. 2010; 122: 117-127.

[107] Ilkit M, Guzel AB. The epidemiology, pathogenesis, and diagnosis of vulvovaginal candidosis: A mycological perspective. Crit Rev Microbiol. 2011; 37: 250-261.

[108] Hay P. Recurrent bacterial vaginosis. Curr Opin Infect Dis. 2009; 22: 82-86.

[109] Menard JP, Fenollar F, Henry M, Bretelle F, Raoult D. Molecular quantification of Gardnerella vaginalis and Atopobium vaginae loads to predict bacterialvaginosis. Clin Infect Dis. 2008; 47(1): 33-43.

[110] Boskey ER, Telsch KM, Whaley KJ, Moench TR, Cone RA. Acid production by vaginal flora in vitro is consistent with the rate and extent of vaginal acidification. Infect Immun. 1999; 67(10): 5170-5175.

[111] Li J, McCormick J, Bocking A, Reid G. Importance of vaginal microbes in reproductive health. Reprod Sci. 2012; 19(3): 235-242.

[112] Fashemi B, Delaney ML, Onderdonk AB, Fichorova RN. Effects of feminine hygiene products on the vaginal mucosal biome. Microb Ecol Health Dis. 2013; 24.

[113] Witkin SS, Linhares IM, Giraldo P: Bacterial flora of the female genital tract: Function and immune regulation. Best Pract Res Clin Obstet Gynaecol. 2007; 21: 347-354.

[114] Mak P, Siwek M, Pohl J, Dubin A. Menstrual hemocidin HbB115- 146 is an acidophilic antibacterial peptide potentiating the activity of human defensins, cathelicidin and lysozyme. Am J Reprod Immunol. 2007; 57: 81-91.

[115] Cohen MS, Black JR, Proctor RA, Sparling PF: Host defences and the vaginal mucosa. A re-evaluation. Scand J Urol Nephrol Suppl. 1984; 86: 13-22.

[116] Yeganegi M, Leung CG, Martins A, Kim SO, Reid G, Challis JR, Bocking AD. Lactobacillus rhamnosus GR-1induced IL-10 production in human placental trophoblast cells involves activation of JAK/STAT and MAPK pathways. Reprod Sci. 2010; 17(11): 1043-1051.

[117] Yeganegi M, Leung CG, Martins A, Kim SO, Reid G, Challis JR, Bocking AD. Lactobacillus rhamnosus GR-1 stimulates colonystimulating factor 3 (granulocyte) (CSF3) output in placental trophoblast cells in a fetal sex-dependent manner. Biol Reprod. 2011; 84(1): 18-25.

[118] Yeganegi M, Watson CS, Martins A, Kim SO, Reid G, Challis JR, Bocking AD. Effect of Lactobacillus rhamnosus GR-1 supernatant and fetal sex on lipopolysaccharideinduced cytokine and prostaglandin-regulating enzymes in human placental trophoblast cells: Implications for treatment of bacterial vaginosis and prevention of preterm labor. Am J Obstet Gynecol. 2009; 200(5): 532e1-e8.

[119] Romero R, Chaiworapongsa T, Kuivaniemi H, Tromp G. Bacterial vaginosis, the inflammatory response and the risk of preterm birth: A role for genetic epidemiology in the prevention of preterm birth. Am J Obstet Gynecol. 2004; 190(6): 1509-1519.

[120] Zaga V, Estrada-Gutierrez G, Beltran-Montoya J, MaidaClaros R, Lopez-Vancell R, Vadillo-Ortega F. Secretions of interleukin-1beta and tumor necrosis factor alpha by whole fetal membranes depend on initial interactions of amnion or choriodecidua with lipopolysaccharides or group B streptococci. Biol Reprod. 2004; 71(4): 1296-1302.

[121] Dominguez-Bello MG, Costello EK, Contreras M, Magris M, Hidalgo G, Fierer N, Knight R. Delivery mode shapes the acquisition and structure of the initial microbiota across multiple body habitats in newborns. Proc Natl Acad Sci U S A. 2010; 107(26): 11971-11975.

[122] Favier CF, de Vos WM, Akkermans AD.Development of bacterial and bifidobacterial communities in feces of newborn babies. Anaerobe. 2003; 9(5): 219-229.

[123] Mackie RI, Sghir A, Gaskins HR. Developmental microbial ecology of the neonatal gastrointestinal tract. Am J Clin Nutr. 1999; 69(5): 1035S-1045S

[124] Grönlund MM, Lehtonen OP, Eerola E, Kero P. Fecal microflora in healthy infants born by different methods of delivery: Permanent changes in intestinal flora after cesarean delivery. J Pediatr Gastroenterol Nutr. 1999; 28(1): 19-25.

[125] Penders J, Thijs C, Vink C, Stelma FF, Snijders B, Kummeling I, van den Brandt PA, Stobberingh EE. Factors influencing the composition of the intestinal microbiota in early infancy. Pediatrics. 2006; 118(2): 511-521.

[126] Turnbaugh PJ, Hamady M, Yatsunenko T, Cantarel BL, Duncan A, Ley RE, Sogin ML, Jones WJ, Roe BA, Affourtit JP, Egholm M, Henrissat B, Heath AC, Knight R, Gordon JI. A core gut microbiome in obese and lean twins. Nature. 2009; 457(7228): 480-484.

[127] Stencel-Gabriel K, Gabriel I, Wiczkowski A, Paul M, Olejek A. Prenatal priming of cord blood T lymphocytes by microbiota in the maternal vagina. Am J Reprod Immunol. 2009; 61(3): 246-252.

[128] Keski-Nisula L, Kyynäräinen HR, Kärkkäinen U, Karhukorpi J, Heinonen S, Pekkanen J. Maternal intrapartum antibiotics and decreased vertical transmission of Lactobacillus to neonates during birth. Acta Paediatr. 2013; 102(5): 480-485.

[129] Reid G, Younes JA, Van der Mei HC, Gloor GB, Knight R, Busscher HJ. Microbiota restoration: Natural and supplemented recovery of human microbial communities. Nat Rev Microbiol. 2011; 9(1): 27-38.

[130] Engel P, Moran NA. The gut microbiota of insects - diversity in structure and function. FEMS microbiol revs. 2013, 1-37.

[131] Cremer S, Armitage SAO, Schmid-Hempel P. Social immunity. Curr Biol. 2007; 17(16): R693-R702.

[132] Verschuere L, Rombaut G, Sorgeloos P, Verstraete W. Probiotic bacteria as biological control agents in aquaculture. Microbiol Molec Biol Revs. 2000; 64(4): 655-671.

[133] Walke JB, Harris RN, Reinert LK, Rollins-Smith L a., Woodhams DC. Social Immunity in Amphibians: Evidence for Vertical Transmission of Innate Defenses. Biotropica. 2011; 2; 43(4): 396-400.

[134] Werner DI, Baker EM, Gonzalez EDC, Sosa IR. Kinship recognition and grouping in hatchling green iguanas. Behav Ecol Sociobiol. 1987; 21(2): 83-89.

[135] Troyer K. Behavioral acquisition of the hindgut fermentation system by hatchling Iguana iguana. Behav Ecol and Sociobiol. 1984; 14(3): 189-193

[136] White J, Richard M, Massot M, Meylan S. Cloacal bacterial diversity increases with multiple mates: Evidence of sexual transmission in female common lizards. PLOS one. 2011; 6(7): $1-5$.

[137] Kulkarni S, Heeb P. Social and sexual behaviours aid transmission of bacteria in birds. Behav Proc. 2007; 74(1): 88-92. 
[138] White J, Mirleau P, Danchin E, Mulard H, Hatch SA, Heeb $P$, et al. Sexually transmitted bacteria affect female cloacal assemblages in a wild bird. Ecol Lett. 2010; 13(12): 15151524.

[139] Albone ES, Perry, GC. Anal sac secretion of the red fox, Vulpes vulpes; volatile fatty acids and diamines: Implications for a fermentation hypothesis of chemical recognition. J Chem Ecol. 1976; 2: 101-111.

[140] Gorman ML. A mechanism for individual recognition by odour in Herpestes auropunctatus (Carnivora: Viverridae). Anim Behav. 1976; 24: 141-145.

[141] Ochman H, Worobey M, Kuo C, Ndjango JN, Peeters M, Hahn BH, et al. Evolutionary Relationships of Wild Hominids Recapitulated by Gut Microbial Communities. PLoS Biol. 2010; 8(11): 1-8.

[142] Nunn CL. Primate Disease Ecology in Comparative and Theoretical Perspective. Am J Primatol. 2012; 74: 497-509.

[143] Lombardo MP. Access to mutualistic endosymbiotic microbes: An underappreciated benefit of group living. Behav Ecol Sociobiol. 2007; 62(4): 479-497.

[144] Montiel-Castro AJ, González-Cervantes RM, BravoRuiseco G, and Pacheco-López G. The microbiotagut-brain axis: Neurobehavioral correlates, health and sociality. Front Integr Neurosci. 2013; 7(70): 1-16.

[145] Mooring, MS, Blumstein DT, Stoner CJ. The evolution of parasite-defence grooming in ungulates. Biol J Linn Soc. 2004; 81: 17-37.

[146] Dunbar RIM. Functional significance of social grooming in primates. Folia Primatol. 1991; 57: 121-131.

[147] Power ML, Schulkin, J. Maternal regulation of offspring development in mammals is an ancient adaptation tied to lactation. Appl Transl Gen. 2013; 2: 55-63.

[148] Oftedal OT. The evolution of milk secretion and its ancient origins. Animal. 2012; 6: 355-368.
[149] Bailey MT, Coe CL. Maternal separation disrupts the integrity of the intestinal microflora in infant rhesus monkeys. Dev Psychobiol. 35: 146-155.

[150] Brunel A, Gouet P. Intestinal microflora of the newborn rat as related to mammary, faecal, and vaginal staphylococci strains isolated from the dam. Can J Microbiol. 1989; 35: 989-993.

[151] Zivkovic AM, German JB, Lebrilla CB, Mills DA. Human milk glycobiome and its impact on the infant gastrointestinal microbiota. PNAS. 2011; 108: S4653-S4658.

[152] Hinde K, German JB. Food in an evolutionary context: Insights from mother's milk. J Sci Food Agric. 2012; 92: 2219-2223.

[153] Hinde K, Milligan LA. Primate Milk: Proximate Mechanisms and Ultimate Perspectives. Evol Anthr. 2011; 23: 9-23.

[154] Benezra A, DeStefano J, Gordon JI. Anthropology of microbes. PNAS. 2012; 109(17): 6378-6381.

[155] Emery Thompson M, Jones JH, Pusey AE, Brewer-Marsden $\mathrm{S}$, Goodall J, et al. Aging and fertility patterns in wild chimpanzees provide insights into the evolution of menopause. Curr Biol. 2007; 17(24): 2150-2156.

[156] Robbins AM, Robbins MM, Gerald-Steklis N, Steklis, HD. Age-related patterns of reproductive success among female mountain gorillas. Am J Phys Anthropol. 2006; 131: 511521.

[157] Wich SA, Utami-Atmoko S, Mitra Setia T, Rijksen H, Schurmann, et al. Life history of wild Sumatran orangutans (Pongo abelii). J Hum Evol. 2004; 47: 385-398.

[158] Hawkes K, O'connell JF, Blurton Jones NG, Alvarez H, Charnov EL. Grandmothering, menopause, and the evolution of human life histories. 1998; 95: 1336-1339.

[159] Seeley R, Stephens T, Tate P. Anatomy and Physiology. 7th Edition. San Francisco: McGraw-Hill, 2006. 